\title{
CSPG4 wt Allele
}

National Cancer Institute

\section{Source}

National Cancer Institute. CSPG4 wt Allele. NCI Thesaurus. Code C52436.

Human CPSG4 wild-type allele is located in the vicinity of $15 q 24.2$ and is approximately 38 $\mathrm{kb}$ in length. This allele, which encodes chondroitin sulfate proteoglycan 4 protein, plays a role in both cellular proliferation and migration. The wild-type allele is involved in the regulation of both vascularization and axonal outgrowth. 